\title{
MEMAKNAI PROFESIONALISME
}

\section{GURU PENDIDIKAN AGAMA KRISTEN MASA KINI}

\author{
Oleh: Ramses Simanjuntak ${ }^{1}$ \\ simandjoentak.ramsester@gmail.com
}

\begin{abstract}
Abstrack
Professionalism is a word that we often say when we see people working with all the skills and abilities that are qualified accompanied by a sense of full responsibility. Professionalism in work can be found in every profession anywhere, including in the teaching profession. By working professionally, a teacher will prioritize quality performance so that in every job the teacher will

be seen as a very noble profession. In relation to Christian Religious Education teachers,

Christian Religious Education teachers should carry out their duties with a full sense of responsibility, because they are called to be partners of God in educating the people. The teachers are God's servants who must continue to learn and emulate the Lord Jesus Christ as the Great Teacher who always cares for the people and leads them to the truth.
\end{abstract}

Keywords: Professional Teacher, Professionalism, Christian Religious Education Teacher

\begin{abstract}
Abstrak
Profesionalisme adalah sebuah kata yang sering kita ucapkan apabila kita melihat orang bekerja dengan segala kecakapan dan keterampillan yang mumpuni disertai oleh rasa tanggung jawab

yang penuh. Profesionalisme dalam bekerja dapat kita jumpai di setiap profesi mana saja, termasuk juga di dalam profesi keguruan. Dengan bekerja secara profesional, seorang guru akan mengutamakan kinerja yang berkualitas sehingga di setiap pekerjaannya guru akan dipandang sebagai profesi yang sangat mulia. Dalam kaitannya dengan guru Pendidikan Agama Kristen, sudah seharusnya seorang guru Pendidikan Agama kristen harus melaksanakan tugasnya dengan penuh rasa tanggung jawab, karena mereka dipanggil untuk menjadi mitra Allah dalam mendidik umat. Para guru adalah hamba Tuhan yang harus terus belajar dan meneladani Tuhan Yesus Kristus sebagai Guru Agung yang senantiasa peduli kepada umat dan menuntun mereka kepada kebenaran.
\end{abstract}

Kata Kunci: Guru Profesional, Profesionalisme, Guru Pendidikan Agama Kristen

\footnotetext{
${ }^{1}$ Penulis adalah Dosen dan Ketua Program Studi Pendidikan Agama Kristen STT Nazarene Indonesia.
} Lulus S1 (S.Th) tahun 2000 dan S2 (M.Pd.K) tahun 2004 dari Sekolah Tinggi Theologi Injili Indonesia. 


\section{Pendahuluan}

Menjadi seorang guru bukanlah hal yang sembarangan. Alkitab berkata: "Saudarasaudaraku, janganlah banyak orang di antara kamu mau menjadi guru; sebab kita tahu, bahwa sebagai guru kita akan dihakimi menurut ukuran yang lebih berat" (Yakobus 3:1). Menjadi guru perlu keseriusan dan profesionalisme yang sungguh untuk melaksanakannya. J. Galbreath berpendapat profesi guru adalah orang yang bekerja atas panggilan hati nurani. Dalam melaksanakan tugas pengabdian pada masyarakat hendaknya didasari atas dorongan atau panggilan hati nurani, sehingga guru akan merasa senang dalam melaksanakan tugas berat mencerdaskan anak didik. ${ }^{2}$

Menurut B.S. Sidjabat dalam bukunya yang berjudul: "Mengajar Secara Profesional" menjelaskan bahwa ciri guru profesional ialah handal dalam merencanakan, mengelola dan menilai tugas mengajar. Artinya guru yang demikian memiliki kompetensi pedagogis, yang memahami seluk-beluk mengajar secara kreatif. ${ }^{3}$

Menurut M. Makaginsar profesi guru adalah orang yang memiliki latar belakang pendidikan keguruan yang memadai, keahlian guru dalam melaksanakan tugas-tugas kependidikan diperoleh setelah menempuh pendidikan keguruan tertentu, dan kemampuan tersebut tidak dimiliki oleh warga masyarakat pada umumnya yang tidak pernah mengikuti pendidikan keguruan, ${ }^{4}$ sedangkan Y. Nasanius mengatakan profesi guru yaitu kemampuan yang tidak dimiliki oleh warga masyarakat pada umumnya yang tidak pernah mengikuti pendidikan keguruan. $^{5}$

\footnotetext{
${ }^{2}$ Kunandar, Guru Profesional, (Jakarta: PT. Raja Grafindo Persada), 2007, hal. 21.

${ }^{3}$ B.S. Sidjabat, Mengajar Secara Profesional, (Bandung: Yayasan Kalam Hidup), 2011, hal. 3.

${ }^{4}$ Moh. Uzer Uzman, Menjadi Guru Profesional, (Bandung: Remaja Rosdakarya), 2001, hal. 17.

${ }^{5}$ Ibid, hal. 18.
} 
Ada beberapa peran yang dapat dilakukan guru sebagai tenaga pendidik, antara lain: pertama, sebagai pekerja profesional dengan fungsi mengajar, membimbing dan melatih. Kedua, pekerja kemanusiaan dengan fungsi dapat merealisasikan seluruh kemampuan kemanusiaan yang dimiliki. Ketiga, sebagai petugas kemaslahatan dengan fungsi mengajar dan mendidik masyarakat untuk menjadi warga negara yang baik. ${ }^{6}$

Dari pernyataan-pernyataan di atas dapatlah ditarik kesimpulan bahwa profesi guru, haruslah dilakukan oleh orang-orang tertentu yang cakap dengan keterampilan yang ada padanya, sehingga menghasilkan kinerja yang mumpuni dan membentuk pribadi yang profesional dalam melaksanakan tugasnya.

Seorang guru profesional seharusnya memiliki empat kompetensi, yaitu kompetensi pedagogis, kognitif, personaliti, dan sosial. Oleh karena itu, selain terampil mengajar, seorang guru juga memiliki pengetahuan yang luas, bijak, dan dapat bersosialisasi dengan baik. Mereka harus, pertama, memiliki bakat, minat, panggilan jiwa, dan idealism. Kedua, memiliki kualifikasi pendidikan dan latar belakang pendidikan yang sesuai dengan bidang tugasnya. Ketiga, memiliki kompetensi yang diperlukan sesuai dengan bidang tugasnya. Di samping itu, mereka juga harus. Keempat, mematuhi kode etik profesi. Kelima, memiliki hak dan kewajiban dalam melaksanakan tugas. Keenam, memperoleh penghasilan yang ditentukan sesuai dengan prestasi kerjanya. Ketujuh, memiliki kesempatan untuk mengembangkan profesinya secara berkelanjutan. Kedelapan, memperoleh perlindungan hukum dalam melaksanakan tugas profesionalnya, dan kesembilan, memiliki organisasi profesi yang berbadan hukum (sumber UU tentang Guru dan Dosen $)^{7}$

\footnotetext{
${ }^{6}$ Piet A. Sahertian, Profil Pendidik Profesional, (Yogyakarta: Andi Offset), 1994, hal. 56.

7 Syafrudin Nurdin, Guru Profesional Dan Implementasi Kurikulum, (Jakarta: Quantum Teaching), 2005, hal. 96.
} 
Dalam Pasal 8, Undang-Undang Republik Indonesia Nomor 14 Tahun 2005 tentang Guru dan Dosen, guru profesional wajib memiliki kualifikasi akademik, kompetensi, sertifikat pendidik. Sehat jasmani dan rohani, serta memiliki kemampuan untuk mewujudkan tujuan pendidikan nasional. ${ }^{8}$

Dengan demikian antara kompetensi dan profesionalisme, harus terikat menjadi satu, sehingga seorang guru dapat menunaikan tugasnya itu dengan benar sesuai dengan panggilan hati nuraninya untuk membawa setiap peserta didik menjadi pribadi-pribadi yang cerdas dan berkarakter unggul bagi terciptanya suatu negara yang kuat dan berbudi pekerrti luhur dan beriman kepada Tuhan Yesus Kristus sebagai Juruselamat pribadi mereka.

Guru yang profesional adalah guru yang berhasil, adapun yang dimaksud dengan guru yang berhasil adalah guru yang peduli dengan kehidupan dan pergumulan peserta didiknya sebagai pribadi, kemudian mampu menuntun peserta didik bukan saja kaya dalam pengetahuan, melainkan juga semakin mengenal, menikmati kasih karunia Allah (Bapa, Putra dan Roh Kudus) agar seharusnya kompeten dalam mengasihi sesamanya seperti dirinya. ${ }^{9}$

Harro Van Brummelen, seorang Profesor Pendidikan Agama Kristen di Trinity Western University Canada mengungkapkan dalam bukunya yang berjudul "Berjalan Dengan Tuhan di dalam Kelas", bahwa di dalam pendidikan agama Kristen, seorang guru Kristen yang profesional harus menanamkan secara kuat di dalam dirinya bahwa guru adalah seorang seniman dan teknisi, guru adalah seorang fasilitator, guru adalah seorang pembawa cerita, guru adalah seorang

\footnotetext{
${ }^{8}$ Undang -Undang Republik Indonesia No. 14, Tahun 2005 tentang Guru dan Dosen, (Jakarta: CV Laksana Mandiri), 2006, hal. 9.

${ }^{9}$ B.S. Sidjabat, Mengajar Secara Profesional, (Bandung: Yayasan Kalam Hidup), 2011, hal. 4.
} 
pengrajin, guru adalah seorang pelayan, guru adalah seorang iman, guru adalah seorang pengajar, dan guru adalah seorang penuntun. ${ }^{10}$

\section{Metode Penelitian}

Dalam pembahasan ini penulis akan membahas tentang memaknai profesionalisme guru Pendidikan Agama Kristen masa kini. Adapun penelitian yang dilakukan dalam pembahasan ini adalah penelitian dengan menggunakan metode literatur. Menurut Dari hasil penelitian literatur ini penulis akan menyimpulkan apa itu profesionalisme guru dan bagaimana memaknai profesionalisme guru itu dalam kehidupan guru Pendidikan Agama kristen Masa Kini?

\section{Pembahasan}

\section{Profesionalisme Guru Pendidikan Agama Kristen Masa Kini}

Di lapangan banyak di antara guru mengajarkan mata pelajaran yang tidak sesuai dengan kualifikasi pendidikan dan latar belakang pendidikan yang dimilikinya. Tidak memiliki kompetensi yang diperlukan sesuai bidang tugas.

Hal itu terindikasi dengan minimnya kesempatan beasiswa yang diberikan kepada guru dan tidak adanya program pencerdasan guru, misalnya dengan adanya tunjangan buku referensi, pelatihan berkala, dan sebagainya. Profesionalisme dalam pendidikan perlu dimaknai he does his job well. Artinya, guru haruslah orang yang memiliki insting pendidik, paling tidak mengerti dan memahami peserta didik. ${ }^{11}$ Guru harus menguasai secara mendalam minimal satu bidang

${ }^{10}$ Harro Van Brummelen, Berjalan Dengan Tuhan di dalam Kelas, (Tangerang: Universitas Pelita Harapan), 2003, hal. 34-41.

${ }^{11}$ Moh. Uzer Uzman, Menjadi Guru Profesional, (Bandung: Remaja Rosdakarya), 2001, hal. 27. 
keilmuan. Guru harus memiliki sikap integritas profesional. Dengan integritas barulah, sang guru menjadi teladan atau role model. ${ }^{12}$

Menyadari banyaknya guru yang belum memenuhi kriteria profesional, guru dan penanggung jawab pendidikan harus mengambil langkah. Salah satu tujuan pendidikan klasik (Yunani-Romawi) adalah menjadikan manusia makin menjadi "penganggur terhormat", dalam arti semakin memiliki banyak waktu luang untuk mempertajam intelektualitas (mind) dan kepribadian (personal). ${ }^{13}$ Peningkatan kesejahteraan. Agar seorang guru bermartabat dan mampu "membangun" manusia muda dengan penuh percaya diri, guru harus memiliki kesejahteraan yang cukup. $^{14}$

Secara definisi kata "guru" bermakna sebagai pendidik profesional dengan tugas utama mendidik, mengajar, membimbing, mengarahkan, melatih, menilai, dan mengevaluasi peserta didik pada jalur pendidikan formal. Sesungguhnya guru dan pendidik merupakan dua hal yang berbeda maknanya. Kata "pendidik" (Bahasa Indonesia) merupakan padanan dari kata educator (Bahasa Inggris). ${ }^{15}$

Di dalam kamus Webster kata educator berarti educationist atau educationalist yang padanannya dalam bahasa Indonesia adalah pendidik, spesialis di bidang pendidikan, atau ahli pendidikan. Kata "guru" (Bahasa Indonesia) merupakan padanan dari kata teacher (Bahasa Inggris). Di dalam kamus Webster, kata teacher bermakna sebagai the person who teach, especially in school atau guru adalah seseorang yang mengajar. ${ }^{16}$

\footnotetext{
12 Ibid, hal. 29.

13 Syafrudin Nurdin, Guru Profesional Dan Implementasi Kurikulum, (Jakarta: Quantum Teaching),

${ }^{14}$ Ibid, hal. 32.

${ }^{15}$ Hasan Alwi, Kamus Besar Bahasa Indonesia Edisi Ketiga, (Jakarta: Balai Pustaka), 2005, hal. 389.

${ }^{16}$ Mulyasa, Menjadi Guru Profesional, (Bandung: PT. Remaja Rosdakarya), 2007, hal. 54.
} 2005, hal. 31 . 
Guru yang profesional adalah guru yang kompeten secara metodologi pembelajaran dan keilmuan. ${ }^{17}$ Tautan antara keduanya tercermin dalam kinerjanya selama transformasi pembelajaran. kata profesional bermakna pekerjaan atau kegiatan yang dilakukan oleh seseorang dan menjadi sumber penghasilan kehidupan yang memerlukan keahlian, kemahiran, atau kecakapan yang memenuhi standar mutu atau norma tertentu serta memerlukan pendidikan profesi. $^{18}$

Conny R. Semiawan mengemukan bahwa kompetensi guru memiliki tiga kriteria yang terdiri dari: ${ }^{19}$

Pertama, Knowledge criteria, yakni kemampuan intelektual yang dimiliki seorang guru yang meliputi penguasan materi pelajaran, pengetahuan mengenai belajar dan tingkahlaku individu, pengetahuan tentang bimbingan dan penyuluhan, pengetahuan tentang kemasyarakatan dan pengetahuan umum.

Kedua, Performance criteria, adalah kemampuan guru yang berkaitan dengan pelbagai ketrampilan dan perilaku, yang meliputi ketrampilan mengajar, membimbing, menilai, menggunakan alat bantu pengajaran, bergaul dan berkomunikasi dengan siswa dan ketrampilan menyusun persiapan mengajar atau perencanaan mengajar.

Ketiga, Product criteria, yakni kemampuan guru dalam mengukur kemampuan dan kemajuan siswa setelah mengikuti proses belajar mengajar.

Dengan demikian jelas bahwa profesi guru merupakan sebuah profesi, yang hanya dapat dilaksanakan secara efektif dan efisien oleh seseorang yang dipersiapkan untuk menguasai kompetensi guru melalui pendidikan dan/atau pelatihan khusus.

\footnotetext{
${ }^{17}$ Ali Imron, Pembinaan Guru Di Indonesia, (Jakarta: Dunia Pustaka), 1995, hal. 50.

${ }^{18}$ Sukirno, Pedoman Kerja Komite Sekolah, (Jakarta: Pustaka Widyatama), 2006, hal. 15.

${ }^{19}$ Conny R. Semiawan, Penerapan Pembelajaran pada Anak, (Jakarta: Indeks), 2009, hal. 93.
} 
Di dalam pasal 7 Undang Undang Republik Indonesia No.14 tahun 2005 tentang Guru dan Dosen disebutkan bahwa prinsip - prinsip profesi guru adalah sebagai berikut: ${ }^{20}$ pertama, memiliki bakat, minat, panggilan jiwa dan idealisme. Kedua, memiliki konitmen untuk meningkatkan mutu pendidikan, keimanan, ketakwaan, dan akhlak mulia. Ketiga, memiliki kualifikasi akademik dan latar belakang pendidikan sesuai dengan bidang tugas. Keempat, memiliki kompetensi yang diperlukan sesuai dengan bidang tugas. Kelima, memiliki tanggungjawab atas pelaksanaan tugas keprofesionalan. Keenam, memperoleh penghasilan yang di tentukan sesuai dengan prestasi kerja. Ketujuh, memiliki kesempatan untuk mengembangkan keprofesionalan secara berkelanjutan dengan belajar sepanjang hayat. Kedelapan, memiliki jaminan perlindungan hukum dalam melaksanakan tugas keprofesionalan; dan kesembilan, memiliki organisasi profesi yang mempunyai kewenangan mengatur hal -hal yang berkaitan dengan tugas keprofesionalan guru.

Hasil studi beberapa ahli mengenai sifat - sifat atau karakteristik - karakteristik profesi itu menghasilkan kesimpulan seperti berikut: ${ }^{21}$ pertama, kemampuan intelektual yang di peroleh melalui pendidikan. Pendidikan di maksud adalah jenjang pendidikan tinggi. Kedua, memiliki pengetahuan spesialisasi. Pengetahuan spesialisasi adalah sesuatu kekhususan penguasaan bidang keilmuan tertentu. Ketiga, memiliki pengetahuan praktis yang dapat digunakan langsung oleh orang lain atau klien. Keempat, memiliki kapasitas mengorganisasikan kerja secara mandiri atau self-organization. Istilah mandiri disini berarti kewenangan akademiknya melekat pada dirinya. Kelima, mementingkan kepentingan orang lain (altruism). Keenam, memiliki kode etik. Kode etik ini merupakan norma - norma yang mengikat guru dalam bekerja. Ketujuh, memiliki sanksi dan tanggung jawab komunitas. Kedelapan, mempunyai sistem upah. Sistem upah yang

\footnotetext{
${ }^{20}$ Undang -Undang Republik Indonesia No. 14, Tahun 2005 tentang Guru dan Dosen, (Jakarta: CV. Laksana Mandiri), 2006, hal. 8.

${ }^{21}$ Piet A. Sahertian, Profil Pendidik Profesional, (Yogyakarta: Andi Offset), 1994, hal. 13.
} 
dimaksud di sini adalah standar gaji. Kesembilan, budaya profesional. Budaya profesi, bissa berupa penggunaan simbol - simbol yang berbeda dengan simbol - simbol untuk profesi lainnya. Pendekatan institusional (the instutional approach) memandang profesi dari segi proses institusional atau perkembangan asosiasional. Pendekatan legatistik (the legatistic approach) yaitu pendekatan yang menekankan adanya pengakuan atas suatu profesi oleh negara atau pemerintah. $^{22}$

Guru harus memiliki kualifikasi akademik sekurang - kurangnya S1/D-IV dan bersertifikat pendidik. Jika seorang guru telah memeliki keduanya, statusnya di akui oleh negara sebagai guru profesional. ${ }^{23}$ Guru profesional adalah mereka yang memiliki kemandirian tinggi ketika berhadapan birokrasi pendidikan dan pusat - pusat kekuasaan lainnya. ${ }^{24}$ Alasan esensial lain di perlukannya pembinaan dan pengembangan guru adalah karakteristik tugas yang terus berkembang seirama dengan perkembangan ipteks, disamping reformasi internal pendidikan itu sendiri. ${ }^{25}$ Secara umum kegiatan itu dibedakan dalam dua jenis, yaitu metode - metode praktis dan teknik - teknik presentasi atau metode - metode simulasi. ${ }^{26}$

Guru bermakna sebagai pendidik profesional dengan tugas utama mendidik, mengajar, membimbing, mengarahkan, melatih, menilai, dan mengevaluasi peserta didik pada jalur pendidikan formal. ${ }^{27}$ Tugas utama itu akan efektif jika guru memiliki derajat kecakapam, atau ketrampilan yang memenuhi standar mutu atau norma etik tertentu.

${ }^{22}$ Ali Imron, Pembinaan Guru Di Indonesia, (Jakarta: Dunia Pustaka), 1995, hal. 31.

${ }^{23}$ Mulyasa, Menjadi Guru Profesional, (Bandung: PT. Remaja Rosdakarya), 2007, hal. 59.

${ }^{24}$ Uzer Usman, Menjadi Guru Profesional, (Bandung: PT. Remaja Rosdakarya), 2002, hal. 86.

${ }^{25}$ Sudarwan, Profesionalisasi dan Etika Profesi Guru, (Jakarta: CV. Alfabeta), 2010, hal. 13.

${ }^{26}$ Mulyasa, Menjadi Guru Profesion, (Bandung: PT. Remaja Rosdakarya), 2007, hal. 63.

${ }^{27}$ Undang -Undang Republik Indonesia No. 14, Tahun 2005 tentang Guru dan Dosen, (Jakarta: CV. Laksana Mandiri), 2006, hal. 3. 
Guru masa depan harus mampu memainkan peran seperti berikut ini: ${ }^{28}$ pertama, sebagai penasihat, guru harus mampu mengumpulkan data dan informasi. Kedua, sebagai perencana, guru memilliki program pribadi yang jelas. Ketiga, sebagai inovator, guru memiliki kemauan untuk melakukan pembaruan dan pembaruan dimaksud berkenan dengan pola pembelajaran. Keempat, sebagai motivator, guru masa depan mampu memiliki motivasi untuk terus belajar dan belajar

Dari konseptual yang di utarakan oleh Mujtahid, ada beberapa strategi yang bisa di gunakan oleh guru untuk menumbuhkan motivasi belajar siswa, yaitu: ${ }^{29}$ pertama, menjelaskan tujuan belajar kepada siswa. Pada permulaan belajar mengajar seharusnya seorang guru menjelaskan mengenai tujuan yang akan dicapainya kepada siswa. Makin jelas tujuan maka makin besar pula motivasi siswa dalam belajar. Kedua, memberikan hadiah untuk siswa yang berprestasi. Hal ini akan memacu semangat mereka untuk bisa belajar lebih giat lagi. Disamping itu, siswa yang belum berprestai belajarnya, berusaha memperbaiki hasil prestasi. Ketiga, mendorong usaha persaingan diantara siswanya untuk meningkatkan prestasi belajarnya, berusaha mempernbaiki hasil prestasi yang telah dicapai sebelumnya. Keempat, memberikan pujian yang sepantasnya bagi siswa yang berprestasi sebagai penghargaan yang bersifat membangun. Kelima, memberikan hukuman yang bersifat mendidik. Keenam, membentuk kebiasaan belajar yang baik. ketujuh, membantu kesulitan belajar siswa secara individual maupun kelompok. Kedelapan, menggunakan metode yang bervariasi. Kesembilan, menggunakan media yang baik dan sesuai dengan tujuan pembelajaran.

Dalam menjalankan tugasnya, seorang guru Pendidikan Agama Kristen juga dituntut untuk profesional. Seorang guru Pendidikan Agama Kristen harus memiliki kualifikasi rohani

\footnotetext{
${ }^{28}$ Masalah manajemen pendidikan di Indonesia, Jakarta: Departemen Pendidikan dan kebudayaan Ditjen Dikdasmen - Dik menum.

${ }^{29}$ Mujtahid, Pengembangan Profesi Guru, (Malang: UIN-Maliki Press), 2011, hal. 33.
} 
yang mumpuni, sebab mereka dipanggil dan terpanggil untuk membawa kehidupan Allah bagi

para peserta didik, sehingga orang lain dapat melihat bahwa mereka benar-benar hidup dengan

kualifikasi rohani yang matang dan mantap.

Kualifikasi rohani tersebut dapat terlihat dari: Pertama, dimana dirinya harus memahami bahwa dia adalah seorang kristen. Ketika Guru memahami dirinya sebagai seorang Kristen, bahwa seorang Kristen mampu memberi dirinya secara penuh kepada Kristus. Didalam Kisah Para Rasul 11:26 diceritakan bahwa bagaimana para pengikut Yesus siap sedia tinggal bersama para murid dan mengajar mereka. Oleh karena demikian sebagai Pendidik Kristen, rela berkorban, dan mampu menjadi pengajar sesuai teladan yang telah diberikan oleh Tuhan Yesus. Bagaimana sikap seorang Kristen? Orang Kristen ialah orang yang percaya dan menyambut sepenuhnya kedudukan dan peran Yesus sebagai Tuhan, Juruselamat dan Raja atas kehidupannya. Maka kualifikasi rohani guru PAK, mampu merespon dan meneladani kehidupan Kristus dengan sungguh-sungguh dan membukan diri untuk didiami oleh Roh Kudus, sebagai penuntun dan penolong dalam melakukan tugas dan tanggung jawab sebagai seorang Guru. Kedua, mampu memahami tugas dan tanggungjawab sebagai guru dalam melaksanakan Tugas keguruan. Sebagai orang Kristen, guru terpanggil untuk bertumbuh kearah pengenalan yang semakin mendalam dan lengkap tentang pribadi Yesus Kristus. Pengenalan tentang pribadi Yesus adalah jalan, kebenaran, dan hidup, membawa orang kepada pengenalan yang sejati akan karya Allah. dalam Yohanes 1:18, jelas bahwa, Yesus menyatakan dengan tegas bahwa diluar Dia, orang tidak dapat melakukan hal yang benar bagi kemuliaan Allah. melalui persekutuan dengan Kristus. ${ }^{30}$

Seorang Guru Kristen semakin menemukan kebenaran yang sesungguhnya. Dan

kebenaran yang dinyatakan Allah kepada setiap orang percaya menyangkut segi kognitif (intelek-pemikiran), segi moral, etis, serta spiritual. Selain itu kebenaran yang harus dikejar oleh Guru Kristen adalah kebenaran realistis, yaitu yang nyata dalam kehidupan. Guru Pendidik agama Kristen, mampu mengajar sesuai kebenaran Alkitab dan apa yang hendak diajarkan bukan hanya sekedar pengetahuan seorang guru tetapi perlu tindakan dan memberi keteladanan. $^{31}$

\footnotetext{
${ }^{30}$ Homrighusen, Pendidikan Agama Kristen, (Jakarta: BPK Gunung Mulia), 1994, hal. 96.

${ }^{31}$ Andar Ismail, Ajarlah Mereka Melakukan, (Jakarta: BPK Gunung Mulia), 2000, hal. 27.
} 
Adapun kualifikasi rohani yang harus dimiliki oleh seorang guru Pendidikan Agama Kristen adalah sebagai berikut: ${ }^{32}$

\section{Mengenal Tuhan Yesus}

Seorang pengajar anak bertanggungjawab mengenalkan Tuhan Yesus kepada anak-anak. Maka, pentingnya seorang guru mengenal Tuhan Yesus secara pribadi. Tuhan Yesus, juruselamat dunia, telah diakui sebagai juruselamat pribadi oleh Guru, sehingga dengan demikian, maka guru Kristen memiliki dasar yang kokoh untuk memperkenalkan Kristus kepada anak-anak didikannya.

\section{Mengenal Firman Tuhan}

Seorang Guru, akan membutuhkan waktu untuk membaca Firman Tuhan setiap hari. Hidup rohani seorang Guru akan diubah dan berkembang jika menyukai firman Allah dan menjadikan firman itu bagian dari hidupnya sehari-hari. Jika seorang Guru hanya membaca Alkitab sesaat sebelum ia mengajar, dia akan kekurangan kewibawaan rohaninya. Guru yang kurang memiliki waktu saat teduh bersama dengan Tuhan, dapat dirasakan oleh anak-anak. kesediaan dan sukacita dalam mengenal firman Tuhan, akan membawa sesuatu kewibawaan dalam mengajar. Gurupun dapat mengajar tanpa dibuat-buat, dan apa yang dia lakukan akan mengalir dengan wajarnya. Dengan demikian, maka seorang guru Kristen akan mengajar berdasarkan pengenalan Kristus.

\section{Menjadi Teladan Rohani Terhadap Murid Rekan Guru bahkan Masyarakat Umum}

Anak-anak tidak hanya akan terkesan dengan apa yang dikatakan oleh guru, tetapi bagaimana guru juga hidup sesuai dengan apa yang dikatakannya itu. Maksudnya ialah seorang

${ }^{32}$ B. S. Sidjabat, Menjadi Guru Profesional: Sebuah Persfektif Kristiani, (Bandung: Yayasan Kalam Hidup), 1994, hal 24. 
guru Kristen tidak hanya mampu mengajar kepada anak-anak agar mengasihi, saling menolong, sementara dirinya sendiri sebagai pengajar, tidak dapat mengasihi dan menolong. Untuk itu, seorang pengajar Kristen, tidak hanya seorang yang intelektual yang memiliki banyak pengetahuan, tetapi pengetahuan akan firman Tuhan harus sesuai dengan Tindakan sehingga dapat disebut profesional.

\section{Menghargai Anak}

Seorang pengajar akan melihat anak-anak dengan kasih sayang Tuhan Yesus. Ia mengerti bahwa setiap anak berharga dihadapan Allah. karena itu, anak juga berharap untuk dia. Guru aka paham bahwa apa yang dia lakukan untuk anak-anak, dia perbuat juga bagi Tuhan Yesus. Dalam hal ini, seorang guru Kristen tidak pilih kasih, tetapi memandang semua anak sama dan diperlakukan sama untuk diperhatikan dan diajar penuh kasih sayang.

Selain itu, menurut seorang tokoh Kristen bernama Kunandar, dia mengatakan bahwa "Guru wajib memiliki kualifikasi akademik, kompetensi, sertifikat pendidik, sehat jasmani dan rohani, serta memiliki kemampuan untuk mewujudkan tujuan pendidikan Nasional. Kualifikasi akademik diperoleh melalui pendidikan tinggi program sarjana atau program diplomat empat. ${ }^{33}$ Kompetensi guru meliputi kompetensi pedagogik, kompetensi kepribadian, kompetensi sosial, kompetensi profesional yang diperoleh melalui pendidikan profesi." Dalam hal ini, jelas menekankan bahwa seorang guru harus memiliki kualifikasi yan mendasar dalam dirinya mengenai profesi yang dia miliki sebagai seorang pendidik, dan juga mampu mengualifikasikan dirinya sendiri untuk meraih standar keguruan yang ia miliki. ${ }^{34}$

\footnotetext{
${ }^{33}$ Kunandar, Guru Profesional, (Jakarta: PT. Raja Grafindo Persada), 2007, hal. 55.

${ }^{34}$ Ibid, hal. 56.
} 
Sebagai Guru atau pendidik agama Kristen, harus mampu memahami hukum-hukum guru yang berlaku, dan juga profesional dalam mengemban tugas sebagai Pendidik Agama Kristen baik keberadaannya ditengah-tengah masyarakat, maupun dalam organisasi gereja.

Seorang guru Kristen harus mengetahui dan memahami Hukum Guru Kristen, adapun Hukum Guru Kristen itu ada 10 yakni: pertama, jangan ada padamu kesenanganmu sendiri sebelum tugasmu selesai. Kedua, jangan membuat bagimu rencana pribadi yang kurang penting sehingga kamu meninggalkan tugasmu pada harimu mengajar. Jangan menyembah sujud pada hiburan yang tidak senonoh atau beribadah dengan kelakuan yang kurang memberi teladan yang baik. Ketiga, jangan menunaikan tugasmu dengan sembarangan, sebab Tuhan akan memandang bersalah orang yang mengajarkan Firman-Nya dengan sembarangan. Keempat, ingatlah dan laksanakanlah tugasmu; enam hari lamanya engkau akan mempersiapkan diri, tetapi jangan melakukan persiapan yang tergesa-gesa pada pagi hari sebelum mengajar. Kelima, hormatilah panggilanmu dan tugasmu, supaya berlanjut pelayananmu dengan sukacita. Keenam, jangan membunuh minat dan potensi murid-muridmu dengan kehadiran yang tidak teratur atau persiapan yang tidak pantas. Ketujuh, jangan mencemarkan kesucian imanmu dalam firman Allah, baik melalui tutur kata atau tingkah lakumu. Kedelapan, jangan mencuri waktu belajar murid-muridmu sendiri, ataupun ketenangan kelas-kelas lain, dengan datang terlambat. Kesembilan, jangan mengucapkan saksi dusta, yaitu dengan lalai mempraktikan apa yang kau ajarkan. Kesepuluh, jangan mengingini hasil yang dangkal, melainkan hasil yang berarti melalui doa, kasih dan usaha yang sungguh-sungguh. ${ }^{35}$

Selain beberapa hukum tersebut diatas, Guru Kristen juga harus mampu bertanggungjawab dengan tujuan pendidikan pengajaran Agama itu sendiri. Menurut Homrighausen, tanggungjawab guru Kristen adalah "Menjadi penafsir iman Kristen, dialah yang

\footnotetext{
${ }^{35}$ Homrighusen, Pendidikan Agama Kristen, (Jakarta: BPK Gunung Mulia),1994, hal. 96.
} 
menguraikan kepercayaan Kristen itu karena ia harus menyampaikan harta dari masa lampau kepada para pemuda yang akan menempuh masa depan."36

Guru juga menjadi seorang gembala bagi muridnya, bertanggungjawab atas hidup rohani mereka, ia wajib membina dan memajukan hidup rohani itu. Guru harus juga menjadi pedoman dan pemimpin, ia tidak boleh menuntun muridnya masuk kedalam kepercayaan Kristen dengan paksaan, melainkan ia harus membimbing mereka dengan halus dan lemah lembut kepada juruselamat dunia. $^{37}$

Dengan memahami pernyataan dari Homrighausen ini, sangatlah erat kaitannya dengan kesepuluh hukum Guru Kristen, dan penulis menganggap bahwa itu adalah bagian yang harus ada dalam kehidupan seorang guru PAK, dan mampu mempraktekkannya ditengah-tengah para muridnya, bahkan juga dikomunitas orang percaya. Akhirnya, guru adalah seorang penginjil bertanggungjawab atas penyerahan diri setiap orang pelajarnya kepada Yesus Kristus. Belum cukup jikalau ia menyampaikan mereka segala pengetahuan tentang Kristus. Tujuan pengajaran itu adalah supaya mereka sungguh-sungguh menjadi murid-murid Tuhan Yesus, yang rajin dan setia. Guru tidak boleh merasa puas sebelum anak didiknya menjadi orang kristen sejati. ${ }^{38}$

\section{Kesimpulan}

Menjadi guru, bukan hanya sekedar lulus dari sekolah pendidikan guru dan memiliki nilai istimewa, tetapi lebih dari pada itu menjadi guru haruslah dibarengi oleh sikap profesionalisme, sebab guru adalah profesi yang mulia. Dalam dunia pendidikan agama Kristen Guru adalah

\footnotetext{
${ }^{36}$ Ibid, hal. 99.

${ }^{37}$ Ibid, hal. 100.

38 Elia Tambunan, PAK dalam Masyarakat Multikultural, (Yogyakarta: Ilumination Publising), 2011,
} hal. 32 . 
orang yang dipanggil untuk melayani bersama Allah. Guru adalah hamba Tuhan yang harus memiliki kualifikasi kehidupan rohani yang mumpuni.

Di era masa kini yang penuh dengan kemajuan teknologi seorang guru pendidikan agama Kristen harus hadir sebagai seorang wakil Allah yang terus memacu dirinya untuk terus optimal dalam menjalankan profesinya, sehingga banyak orang boleh mengenal Kristus melalui hidup guru tersebut. Guru pendidikan agama Kristen harus profesional dan harus mencontohkan kehidupan Kristus bagi peserta didik. 


\section{DAFTAR PUSTAKA}

Alwi, Hasan. Kamus Besar Bahasa Indonesia Edisi Ketiga, Jakarta: Balai Pustaka, 2005.

Brummelen, Harro Van, Berjalan Dengan Tuhan Di Dalam Kelas, Tangerang: Universitas Pelaita Harapan, 2003.

Homrighusen, Pendidikan Agama Kristen, Jakarta: BPK Gunung Mulia, 1994.

Imron, Ali, Pembinaan Guru Di Indonesia, Jakarta: Dunia Pustaka, 1995.

Ismail, Andar, Ajarlah Mereka Melakukan, Jakarta: BPK Gunung Mulia, 2000.

Kunandar, Guru Profesional, Jakarta: PT. Raja Grafindo Persada, 2007.

Masalah manajemen pendidikan di Indonesia, Jakarta: Departemen Pendidikan dan Kebudayaan Ditjen Dikdasmen - Dik menum.

Mujtahid, Pengembangan Profesi Guru, Malang: UIN-Maliki Press, 2011.

Mulyasa, Menjadi Guru Profesional, Bandung: PT. Remaja Rosdakarya, 2007.

Nurdin, Syafrudin, Guru Profesional Dan Implementasi Kurikulum, Jakarta: Quantum Teaching, 2005.

Sahertian, Piet A., Profil Pendidik Profesional, Yogyakarta: Andi Offset, 1994.

Semiawan, Conny R., Penerapan Pembelajaran pada Anak, Jakarta: Indeks, 2009.

Sidjabat, B.S., Mengajar Secara Profesional, Bandung: Yayasan Kalam Hidup, 2011.

Sudarwan, Profesionalisasi dan Etika Profesi Guru, Jakarta: CV. Alfabeta, 2010.

Sukirno, Pedoman Kerja Komite Sekolah, Jakarta: Pustaka Widyatama, 2006.

Tambunan, Elia, PAK dalam Masyarakat Multikultural, Yogyakarta: Ilumination Publising, 2011. 
Undang-Undang Republik Indonesia No. 14, Tahun 2005 tentang Guru dan Dosen, Jakarta: CV. Laksana Mandiri, 2006.

Usman, Uzer, Menjadi Guru Profesional, Bandung: PT. Remaja Rosdakarya, 2002.

Uzman, Moh. Uzer, Menjadi Guru Profesional, Bandung: Remaja Rosdakarya, 2001. 